
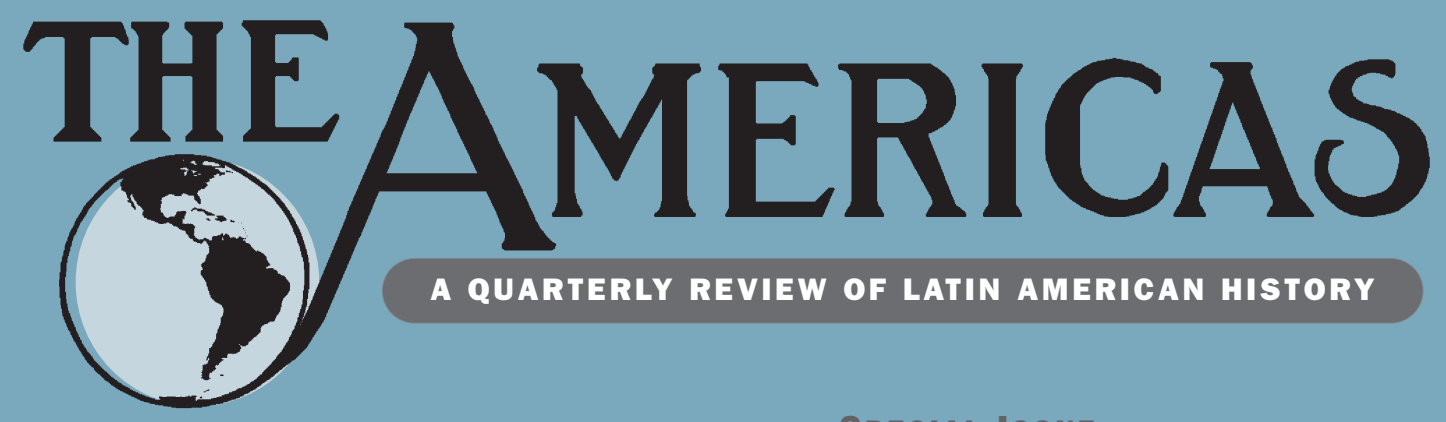

A QUARTERLY REVIEW OF LATIN AMERICAN HISTORY

SPECIAL ISSUE:

INDIGENOUS LIMINALITIES: ANDEAN ACTORS AND

$\vee \circ \square u m e \quad 72$

J a n u a เ y 201015

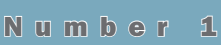

\section{TRANSLATORS OF COLONIAL CULTURE}

A L C IRA DUEÑAS

INTRODUCTION:

Andeans Articulating Colonial Worlds

José Carlos de la PUENTE Luna

THAT WHICH BELONGS TO ALL:

Khipus, Community, and Indigenous Legal Activism in the Early Colonial Andes

ALCIRA DUEÑ AS

THE LIMA INDIAN LETRADOS:

Remaking the República de Indios in the Bourbon Andes

MAYA STANFIELD - M AZZ I

WEAVING AND TAILORING THE ANDEAN CHURCH:

Textile Ornaments and Their Makers in Colonial Peru

A N A N A COHEN SUAREZ

FROM THE JORDAN RIVER TO LAKE TITICACA:

Paintings of the Baptism of Christ in Colonial

Andean Churches

BOOKS IN BRIEF

INTER-AMERICAN NOTES

REVIEWS

\section{Published by}

Academy of American

Franciscan History

CAMBRIDGE

UNIVERSITY PRESS 


\section{BOARD OF EDITORS}

\section{JEFFREY M. BURNS, Director \\ Academy of American Franciscan History, USA \\ Liason to the Academy of American Franciscan History \\ JOHN F. SCHWALLER \\ University at Albany, USA}

Editor

BEN VINSON III

George Washington University,

USA

\section{GEORGETTE MAGASSY DORN \\ Library of Congress, USA \\ BARBARA A. SOMMER \\ Gettysburg College, USA \\ ERIC ZOLOV \\ Stony Brook University, USA}

\author{
Associate Editor \\ JAMES M. KRIPPNER \\ Haverford College, USA
}

Assistant Editors

LEO GAROFALO

Connecticut College, USA

Barbara A. Tenenbaum

Library of Congress, USA

ANN ZULAWSKI

Smith College, USA

\author{
Managing Editor \\ DONALD F. STEVENS \\ Drexel University, USA
}

\section{AREA EDITORS}

KATHERINE BLISS

Georgetown University, USA

MATT CHILDS

University of South Carolina, USA

ERIK CHING

Furman University, USA

DEBORAH COHEN

University of Missouri, St. Louis, USA

LAUREN DERBY

University of California, Los Angeles, USA
BARBARA GANSON

Florida Atlantic University, USA

CHRISTINe HunEFELT

University of California, San Diego, USA

THOMAS KLUBOCK

University of Virginia, USA

BRYAN MCCANN

Georgetown University, USA

JAMES SWEET

University of Wisconsin, Madison, USA

\section{SENIOR EDITORS}

WILLIAM H. BEEZLEY

University of Arizona, USA

AMY TURNER BUSHNELL

Brown University, USA

JEFFREY GOULD

Indiana University, USA

LOWELL GUDMUNDSON

Mount Holyoke College, USA

ERICK LANGER

Georgetown University, USA

LUIS CARLOS MANTILLA, O.F.M.

Universidad de San Buenaventura, Colombia
CHERYL MARTIN

University of Texas, El Paso, USA

ALIDA C. METCALF

Rice University, USA

Francisco MORALES, O.F.M.

Mexico City, Mexico

LOUIS A. PÉREZ JR.

University of North Carolina, Chapel Hill, USA

JOANNE RAPPAPORT

Georgetown University, USA

MATTHEW RESTALL

Pennsylvania State University, USA

\section{Editorial Assistants}

JOE CLARK

Johns Hopkins University, USA
CASSIE HOMER

Drexel University, USA 
Dear Colleagues,

It gives me great pleasure to announce a new and historic partnership between The Americas and Cambridge University Press. Beginning with this issue, Cambridge University Press becomes the publisher of the journal, a change that will enable us to reach a broader international audience, while offering new content and online features. It will also allow the publication to achieve greater efficiencies in its production, promotion, and distribution.

Our editorial offices will remain at Drexel University, and our time-honored editorial procedures - including the rigorous in-house review and double-blind peer review process-will remain in place. As we launch the new partnership, we are designating the January 2015 issue as No. 1 of Vol. 72, marking a departure from our traditional practice of designating the July issue as the first of a new volume.

We are excited about the new features that will be introduced shortly and expanded upon in the years to come, and hope that you share in and enjoy them with us. As always, we appreciate your loyal readership and support of The Americas.

Sincerely,

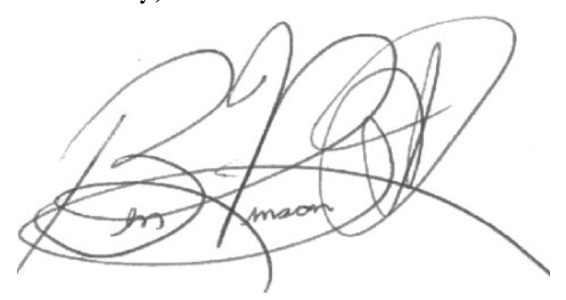

Ben Vinson III

Editor-in-Chief

The Americas 


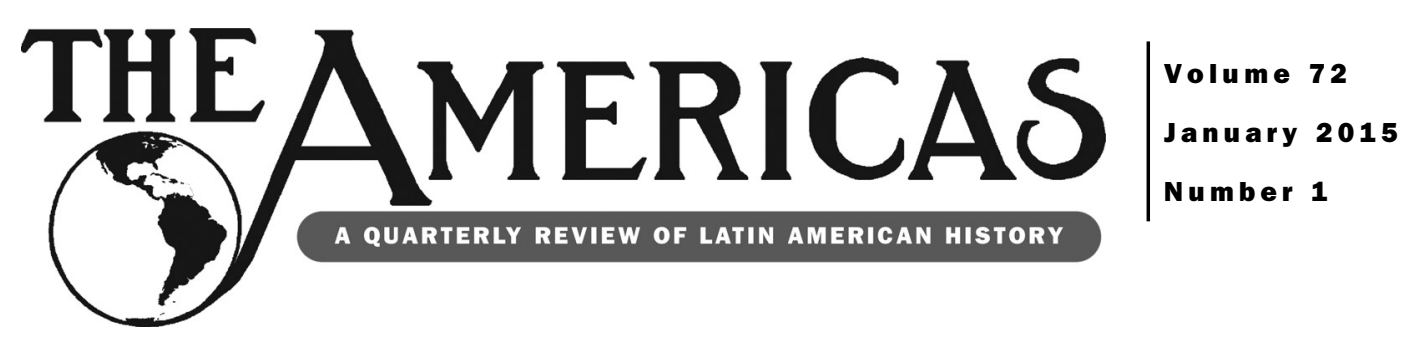

3 INTRODUCTION:

Andeans Articulating Colonial Worlds

Alcira dueñas

19 That Which Belongs to All:

Khipus, Community, and Indigenous Legal Activism in the Early Colonial Andes

José Carlos de la puente luna

55 The Lima Indian LETRAdOS:

Remaking the República de Indios in the Bourbon Andes

Alcira dueñas

77 Weaving and Tailoring the Andean Church:

Textile Ornaments and Their Makers in Colonial Peru

MAYA STANFIELD-MazZI

103 From the Jordan River to Lake Titicaca:

Paintings of the Baptism of Christ in Colonial Andean

Churches

\section{Ananda Cohen Suarez}

141 Books IN BRIEF

149 InTER-AMERICAN Notes

151 Reviews

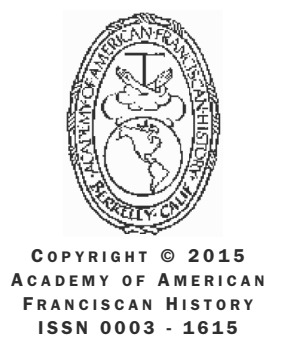




\section{REVIEWS}

\section{BOOKS IN BRIEF}

141 Vargas Llosa and Latin American Politics. Edited by Juan E. De Castro and Nicholas Birns.

142 Economic Development Strategies and the Evolution of Violence in Latin America. Edited by William Ascher and Natalia Mirovitskaya.

143 Cuban Economic and Social Development: Policy Reforms and Challenges in the 21st Century. Edited by Jorge I. Domínguez, Omar Everleny Pérez Villanueva, Mayra Espina Prieto, and Lorena Barberia.

144 Cuban Economists on the Cuban Economy. Edited by Al Campbell.

146 Neoliberalism, Interrupted: Social Change and Contested Governance in Contemporary Latin America. Edited by Mark Goodale and Nancy Postero.

\section{REVIEWS}

151 The Lettered Mountain: A Peruvian Village's Way with Writing. By Frank Salomon and Mercedes Niño-Murcia.

\section{Alan Durston}

\section{CULTURAL/LITERARY STUDIES}

153 Foundational Arts: Mural Painting and Missionary Theater in New Spain.

By Michael K. Schuessler.

\section{Barbara E. Mundy}

\section{ETHNOHISTORY/INDIGENOUS POLITICS}

154 Juan Gregorio Palechor: The Story of My Life. By Myriam Jimeno.

\section{Herbert Braun}

156 "Strange Lands and Different Peoples": Spaniards and Indians in Colonial Guatemala.

By W. George Lovell, Christopher Lutz, Wendy Kramer, William R. Sweezey.

\section{Robinson A. Herrera}


157 Indians and the Political Economy of Colonial Central America, 1670-1810.

By Robert W. Patch.

\section{Sylvia Sellers-García}

159 The Disappearing Mestizo: Configuring Difference in the Colonial New Kingdom of Granada.

By Joanne Rappaport.

\section{Nicole von Germeten}

160 Before L.A.: Race, Space, and Municipal Power in Los Angeles, 1781-1894.

By David Samuel Torres-Rouff.

\section{Miroslava Chávez-García}

162 Indigenous Agency in the Amazon: The Mojos in Liberal and Rubber-Boom Bolivia, 1842-1932.

By Gary Van Valen.

\section{Erick D. Langer}

164 Mysteries of the Jaguar Shamans of the Northwest Amazon. By Robin M. Wright.

\section{Janet Chernela}

\section{GENDER AND SEXUALITY}

166 Masculinity after Trujillo: The Politics of Gender in Dominican Literature.

By Maja Horn.

\section{Fernando Valerio-Holguín}

167 Of Beasts and Beauty: Gender, Race, and Identity in Colombia. By Michael Edward Stanfield.

\section{Pamela S. Murray}

\section{GLOBAL AND TRANSNATIONAL HISTORY}

169 Maximilian and Carlota: Europe's Last Empire in Mexico. By M. M. McAllen.

\section{David Coffey}

171 Fevered Measures: Public Health and Race at the Texas-Mexico Border, 1848-1942.

By John Mckiernan-González.

Linda B. Hall 
173 Americans All: Good Neighbor Cultural Diplomacy in World War II.

By Darlene J. Sadlier.

Justin Hart

\section{HISTORY AND MEMORY}

174 The Structure of Cuban History: Meanings and Purpose of the Past. By Louis A. Pérez Jr.

William Van Norman

176 The Post-Dictatorship Generation in Argentina, Chile, and Uruguay: Collective Memory and Cultural Production. By Ana Ros.

\section{Cath Collins}

\section{NATION BUILDING AND NATIONALISM}

178 Maestra. Film.

By Catherine Murphy

Katherine A. Gordy

179 Oy, My Buenos Aires: Jewish Immigrants and the Creation of Argentine National Identity.

By Mollie Lewis Nuowen.

\section{Ariana Huberman}

180 Constitutive Visions: Indigeneity and Commonplaces of National Identity in Republican Ecuador.

By Christa J. Olson.

\section{Michele Greet}

182 “We Are Now the True Spaniards." Sovereignty, Revolution, Independence, and the Emergence of the Federal Republic of Mexico, 1808-1824.

By Jaime E. Rodríguez.

\section{Barbara A. Tenenbaum}




\section{Contributors}

Ananda Cohen Suarez is Assistant Professor of History of Art at Cornell University, with a specialty in the pre-Columbian and colonial Andes. Her book manuscript, titled Heaven, Hell, and Everything in Between: History and Politics in Colonial Peru, is under advance contract with the University of Texas Press. She has published articles on issues of cross-cultural exchange in Andean art in Colonial Latin American Review and Alpanchis, and has a forthcoming essay on race in colonial Andean visual culture to be included in the edited volume Envisioning Others: Race, Color, and the Visual in Iberia and Latin America, to be published in 2015. Her next scholarly project investigates the impact of indigenismo on the historiography of colonial Andean art.

José Carlos de la Puente Luna is Assistant Professor of History at Texas State University. His research focuses on indigenous legal and political culture in early colonial Peru. He is the author of Los curacas hechiceros de Jauja: batallas mágicas y legales en el Perú colonial (2007) and co-editor with Marco Curatola Petrocchi of El quipu colonial: estudios y materiales (2013). His work has been published in the journals Colonial Latin American Review, Allpanchis, Histórica, Revista Andina, and the Bulletin de l'Institut Français d'Études Andines. He is currently working on a book-length project, tentatively titled "Andean Cosmopolitans: Indigenous Journeys to the Habsburg Royal Court."

Alcira Dueñas is an international scholar and Associate Professor of Latin American History at the Ohio State University-Newark. She works on colonial Andean ethnohistory with a focus on the formation of local indigenous knowledge, its transatlantic intertextuality, and the formation of colonial culture. She published Indians and Mestizos in the 'Lettered City': Reshaping Justice, Social Hierarchy and Political Culture in Colonial Peru, in 2010. Her research as an author and editor has been published in academic journals across the United States, Peru, and Colombia, and she has been the recipient of research awards from Fulbright, the National Endowment for the Humanities, the Max-Planck Institute (Frankfurt), and her home institution. Her current research examines the everyday workings of the república de indios through a reconstruction of the legal and social practices of the indigenous cabildos to illuminate the intricate stories of Spanish empire building at the local and everyday level.

Maya Stanfield-Mazzi is Assistant Professor of Art History at the University of Florida, specializing in pre-Columbian and colonial Latin American art. She received her doctorate in Art History from the University of California at 
Los Angeles, and has been a visiting professor at Tulane University. Her book Object and Apparition: Envisioning the Christian Divine in the Colonial Andes (2013) analyzes the fundamental role played by images in the establishment of Christianity in the Andean region. Her current work on liturgical textiles explores the meaning of cloth in the Spanish American church. 